\title{
A tradução funcionalista do gênero textual peça teatral para o ensino da variação linguística em espanhol ${ }^{1}$ \\ The functionalist translation of text theater piece genre to the teaching of the Spanish language variation
}

\author{
Valdecy de Oliveira Pontes* \\ Livya Lea de Oliveira Pereira**
}

\begin{abstract}
RESUMO: Atualmente, a área de estudos da tradução tem desenvolvido pesquisas que exploram seu aspecto interdisciplinar. No contexto de tradução e ensino de línguas estrangeiras, alguns estudos têm tido resultados positivos ao unir atividades de tradução com a prática de sequências didáticas com gêneros textuais autênticos (BARRIENTOS, 2014; DEMÉTRIO, 2014; LAIÑO, 2014). Portanto, este artigo propõe a prática da tradução funcionalista do gênero textual peça de teatro, na forma de sequência didática, para abordar casos concretos de variação linguística na língua espanhola. Para isso, baseamos nosso trabalho na Teoria Funcionalista da Tradução (REISS, VERMEER, 1996; NORD, 1991, 1994, 1996, 2012), bem como na aproximação entre tradução e variação linguística (BOLAÑOSCUELLAR, 2000; MAYORAL, 1998, BORTONI-RICARDO, 2005; TRAVAGLIA, 2013; PONTES, 2014) e no dispositivo de sequências didáticas com gêneros textuais (DOLZ, NOVERRAZ, SCHENEUWLY, 2004; CRISTÓVÃO, 2009; COSTAHÜRBES, SIMIONE, 2014). Como uma proposta de ensino, exemplificamos o projeto inicial de uma sequência didática com a tradução do gênero textual peça de teatro com um foco na abordagem da variação linguística nas formas de tratamento para a $2^{\mathrm{a}}$ pessoa em diferentes países falantes de língua espanhola. Essa estratégia didática pode proporcionar o

ABSTRACT: Currently, the Translation Studies area has developed research that explores its interdisciplinary aspect. Within the context of translation and foreign language teaching, some studies have had positive results by joining translation activities with the practice of didactic sequences with authentic text genres (BARRIENTOS, 2014; DEMÉTRIO, 2014; LAIÑO, 2014). Therefore, this essay proposes the practice of functionalist translation of the theater play genre, in the form of a didactic sequence, to address actual cases of linguistic variation in the Spanish language. For this purpose, we based our work on the Functionalist Theory of Translation (REISS, VERMEER, 1996; NORD, 1991, 1994, 1996, 2012), as well as on the approximation between translation and linguistic variation (BOLAÑOS-CUELLAR, 2000; MAYORAL, 1998, BORTONIRICARDO，2005; TRAVAGLIA， 2013; PONTES, 2014) and on the device of didactic sequences with text genres (DOLZ, NOVERRAZ, SCHENEUWLY, 2004; CRISTÓVÃO， 2009; COSTA-HÜRBES, SIMIONE, 2014). As a teaching proposal, we provide the example of the initial project of a didactic sequence with the translation of the theater play genre with a focus on the approach to the linguistic variation in the forms of address for the $2^{\text {nd }}$ person in different Spanish-speaking countries. This didactic strategy can allow the enhancement and
\end{abstract}

\footnotetext{
${ }^{1}$ Este artigo é o recorte de uma pesquisa de mestrado.

* Professor Doutor em Linguística, Universidade Federal do Ceará (UFC).

**Mestranda da Universidade Federal do Ceará (UFC); bolsista da Fundação Cearense de Apoio ao Desenvolvimento Científico e Tecnológico (FUNCAP).
} 
aprimoramento e desenvolvimento das habilidades linguísticas dos aprendizes, bem como conscientizá-los sobre a heterogeneidade das línguas envolvidas no processo de tradução.

PALAVRAS-CHAVE: Tradução Funcionalista. Variação linguística. Sequência didática. Língua espanhola. development of the learners' language skills, as well as raise their awareness about the heterogeneity of the languages involved in the translation process.

KEYWORDS: Functionalist Translation. Linguistic variation. Didactic sequences. Spanish language.

\section{Introdução}

A língua espanhola é falada, oficialmente, por mais de 470 milhões pessoas, de acordo com dados do Instituto Cervantes (2014). Diversos países possuem o espanhol como língua oficial, deste modo, no contexto de ensino, os professores desta língua confrontam-se com o desafio de abordar a diversidade linguística sem cair em superficialidades, curiosidades ou estereótipos e preconceitos linguísticos. No Brasil, este desafio é ainda maior, visto que a heterogeneidade da própria língua portuguesa (LM dos estudantes), nas práticas escolares, ainda é pouco reconhecida e raro motivo de reflexão em sala de aula. (FARACO, 2015, p. 20). Além disso, pesquisas afirmam que a maioria dos materiais didáticos de espanhol, utilizada no Brasil, é proveniente da península, fato que resulta em uma maior valorização da variedade espanhola frente às variedades hispano-americanas, as quais, muitas vezes, são apresentadas em breves textos ou curiosidades em tais materiais. (BUGUEL, 1998; SANTOS, 2002; KRAVISKI, 2007; PONTES, 2009). No entanto, embora seja utópico um livro didático (doravante LD) que contemple toda a variação linguística da língua espanhola, devido a limitações de espaço e padrões editoriais, o professor de línguas não está isento de apresentar a heterogeneidade da língua e suas outras variedades, para além da que ele utiliza em sala de aula ou da que se apresenta no LD, conforme nos orienta as OCNEM-LE - Orientações Curriculares Nacionais para o Ensino Médio de Língua Estrangeira (2006).

Assim, ao adotar um LD, caberá uma reflexão crítica por parte do docente de espanhol sobre a abordagem da variação linguística, inclusive, seria oportuno buscar outros meios para apresentá-la, no sentido de promover a conscientização dos aprendizes sobre a heterogeneidade inerente às línguas, caso o LD não contemple este fenômeno a contento. Diante deste contexto, este artigo propõe o uso da Tradução Funcionalista aliada ao dispositivo de Sequências Didáticas com o gênero peça de teatro, a fim de analisar casos concretos de variação linguística, no uso das formas de tratamento pronominais de $2^{\mathrm{a}}$ pessoa do espanhol e do português (brasileiro). 
Neste sentido, este artigo divide-se nos seguintes tópicos: 1. Introdução; 2. A Tradução Funcionalista e o ensino da variação linguística; 3.A potencialidade da tradução funcionalista de peças teatrais para o ensino da variação linguística na língua espanhola; 4. Traduzindo peças teatrais em forma de sequência didática: uma proposta para o ensino da variação linguística nas formas de tratamento; e, 5. Considerações finais.

A seguir, discorremos sobre a potencialidade da tradução funcionalista de peças teatrais para o ensino da variação linguística na língua espanhola

\section{A Tradução Funcionalista e o ensino da variação linguística}

$\mathrm{Na}$ década de 70 , em oposição às abordagens linguísticas formalistas, surge a perspectiva funcionalista, como escola linguística. Nesta, as funções da linguagem possuíam papel central e estavam diretamente relacionadas aos fatores que intervinham na comunicação e intenção pragmática. Logo, entendia-se a linguagem como prática de interação social. Tal visão de língua, no contexto do Ensino de LE, influenciou a abordagem nócio-funcional e, posteriormente, a abordagem comunicativa.

No âmbito dos Estudos da Tradução, esta visão, também, ganhou força e influenciou a vertente alemã conhecida como Teoria Funcional da Tradução ou Tradução Funcionalista. (ZIPSER, POLCHLOPEK, 2011). Esta teoria busca desprender o ato tradutório do puramente linguístico, para incluir aspectos contextuais, culturais e interacionais. Esta vertente teve como principais precursores Reiss e Vermeer (1996), os quais propuseram os seguintes conceitos basilares:

a translação ${ }^{2}$ está em função de seu Eskopos (objetivo, finalidade); a translação é uma oferta informativa em uma cultura final e em sua língua sobre uma oferta informativa procedente de uma cultura de origem e de sua língua; a oferta informativa de uma translação se apresenta como transferência que reproduz uma oferta informativa de partida. Esta reprodução não é reversível de um modo unívoco. (tradução nossa) ${ }^{3}$. (REISS; VERMEER,1996, p. 89)

\footnotetext{
${ }^{2} \mathrm{Na}$ escola alemã de tradução funcionalista, este termo abrange a tradução e a interpretação de línguas. No entanto, para este estudo, usaremos translação como sinônimo de tradução.

${ }^{3}$ Citação original: “(1) La translación está en función de su escopo. (2) La translación es una oferta informativa en una cultura final y en su lengua sobre una oferta informativa procedente de una cultura de origen y de su lengua. (3) La oferta informativa de una translación se presenta como transferencia que reproduce una oferta informativa de partida. Esta reproducción no es reversible de un modo unívoco. (REISS; VERMEER, 1996, p. 89)
} 
Na concepção dos autores, a translação requer uma dupla ação: analisar as condições de produção do texto base (TB) ou texto de partida e analisar as condições de produção do texto meta (TM), isto é, o texto de chegada. (REISS, VERMEER,1996, p. 14). Para esta questão, Cristiane Nord (1991) elaborou um modelo de análise pré-tradutório, o qual baseia-se na análise exaustiva dos aspectos intra e extratextuais da situação comunicativa do texto base (original) e do texto meta (tradução), nas palavras da autora:

Empregando um modelo de análise exaustivo que considere os fatores intra e extratextuais, o tradutor estabelece a função-em-cultura de um texto base dado, para compará-la com a (pretendida) função-em-cultura de um texto meta encomendado, distinguindo os elementos (funcionais) do TB que podem ou devem se manter iguais no processo de tradução dos que terão que se adaptar às exigências da cultura meta (tradução nossa) ${ }^{4}$. (NORD, 2012, p.23)

Nesta perspectiva, Nord (2012) expõe que a translação é a produção de um TM funcional que mantenha uma interdependência com um TB, especificada conforme o seu propósito comunicativo. Para alcançar a essa funcionalidade, é necessário analisar os aspectos intra e extratextuais do TB e compará-los com o contexto de produção do TM, assim, a autora apresenta o seguinte modelo de análise pré-tradutório, baseado na inter-relação dos aspectos extratextuais e intratextuais:

\footnotetext{
${ }^{4}$ Citação original: "Empleando un modelo analítico exhaustivo que considere los factores intra y extratextuales, el traductor establece la función-en-cultura de un texto base dado, para compararla con la (pretendida) función-encultura del texto meta encomendado, distinguiendo los elementos (funcionales) del TB que pueden o deben mantenerse iguales en el proceso de traducción de los que han de adaptarse a las exigencias de la cultura meta." (NORD, 2012, p.23)
} 
Quadro 1. Análise textual pré-tradutória, segundo Nord (2012, p.155).

\begin{tabular}{|c|c|c|c|}
\hline & $\begin{array}{c}\text { PERFIL DO TEXTO } \\
\text { BASE }\end{array}$ & TRANSFERENCIA & $\begin{array}{c}\text { PERFIL DO TEXTO } \\
\text { META }\end{array}$ \\
\hline & \multicolumn{3}{|c|}{ A. FATORES EXTRALINGUÍSTICOS } \\
\hline \multicolumn{4}{|l|}{ EMISSOR } \\
\hline \multicolumn{4}{|l|}{ INTENÇÃO } \\
\hline \multicolumn{4}{|l|}{ RECEPTOR } \\
\hline \multicolumn{4}{|l|}{ MEIO } \\
\hline \multicolumn{4}{|l|}{ LUGAR } \\
\hline \multicolumn{4}{|l|}{ TEMPO } \\
\hline \multicolumn{4}{|l|}{ MOTIVO } \\
\hline \multicolumn{4}{|l|}{\begin{tabular}{|l|l|} 
FUNÇÃO \\
\end{tabular}} \\
\hline & \multicolumn{3}{|c|}{ B. FATORES INTRALINGUÍSTICOS } \\
\hline \multicolumn{4}{|l|}{ TEMA } \\
\hline \multicolumn{4}{|l|}{ CONTEÚDO } \\
\hline \multicolumn{4}{|l|}{ PRESSUPOSIÇÕES } \\
\hline \multicolumn{4}{|l|}{ COMPOSIÇÃO } \\
\hline \multicolumn{4}{|l|}{$\begin{array}{l}\text { ELEMENTOS NÃO } \\
\text { VERBAIS }\end{array}$} \\
\hline \multicolumn{4}{|l|}{ LÉXICO } \\
\hline \multicolumn{4}{|l|}{ SINTÁXE } \\
\hline \multicolumn{4}{|l|}{ SUPRASEGMENTAIS } \\
\hline & C. EI & FEITO COMUNICA & TIVO \\
\hline EFEITO & & & \\
\hline
\end{tabular}

Nord (2012, p. 154) explicita, ainda, exemplos de aplicação didática do seu modelo de análise pré-tradutória, no âmbito da Didática de Tradução. Porém, não descarta o seu uso no contexto de Ensino de LE, desde que não se limite à análise linguística do TB ou às intenções do autor e a sua verbalização. Neste viés, atualmente, há algumas pesquisas com resultados positivos acerca da aplicação deste modelo de análise pré-tradutório no contexto de ensino de línguas, tais como Barrientos (2014), Demétrio (2014) e Laiño (2014). Tais pesquisas basearam-se na aplicação da tradução funcional de gêneros textuais autênticos, em forma de sequência didática, com grupos de alunos de Letras-Língua Espanhola da UFSC.

Acerca da aproximação entre a atividade tradutória e o conhecimento sociolinguístico, diversos autores já a destacaram, tais como, Bolaños-Cuéllar (2000), Mayoral (1998), Travaglia (2013), Bortoni-Ricardo (2005) e Pontes (2014). A Sociolinguística concebe a íntima interrelação dos aspectos linguísticos e extralinguísticos, assim como a Tradução Funcionalista. Ambas as áreas de estudos surgem em oposição às concepções formalistas de língua, portanto, compartilham a ideia de que a língua é social e não pode ser vista isolada de seu contexto sóciohistórico-cultural de uso. Ademais, tanto a Tradução Funcionalista quanto a Sociolinguística Variacionista analisam os condicionamentos linguísticos e extralinguísticos imbricados no uso efetivo da língua. Nord (1994) assevera que a tradução, na perspectiva funcional, tem que adaptar-se às normas e convenções culturais de uma dada cultura e, nessa questão, os estudos 
sociolinguísticos também podem contribuir à tradução, ao buscar descrever as normas sociais ${ }^{5}$ de uma dada língua. A autora reconhece a diversidade cultural e, por conseguinte, a linguística, ao pontuar que:

Parece lógico, então, que existem diferenças de comportamento, também, dentro de uma entidade nacional ou linguística e semelhanças de comportamento entre os membros de dois membros de duas entidades vizinhas. As fronteiras de um âmbito cultural não são claras nem estão firmadas de uma vez por todas. Dentro de um determinado grupo pode ter comportamento comum em um campo (por exemplo: língua) e comportamentos diferentes em outro (por exemplo, formas de cortesia), como por exemplo o caso da Alemanha e da Áustria. (tradução nossa) ${ }^{6}$. (NORD, 1994, p. 106)

Bortoni-Ricardo (2005) chama a atenção para a relação entre a Sociolinguística e os Estudos da Tradução, ao afirmar que aquela, ao pressupor a relação dialética entre a forma linguística e a função definida no contexto social, pode prestar grande contribuição às atividades que implicam confronto entre línguas, tal como a tradução. Neste viés, Bolaños-Cuéllar (2000, p.158) defende, no marco da interdisciplinaridade dos Estudos da Tradução, que a Sociolinguística pode contribuir à compreensão, análise e possíveis soluções de problemas de tradução, no tocante à preservação das formas de tratamento de uma língua a outra, conservação de socioletos, gírias, registros, etc., durante o processo de tradução e em seu produto textual.

Por outro lado, o autor afirma que apesar da existência, em toda língua, de variação diatópica (variedades geográficas), diastrática (tecnoletos, gírias, socioletos) e diafásica (diferentes registros: formal, informal, familiar, etc.), o tradutor, também, deve levar em consideração a existência de uma norma-padrão, que é caracterizada por ter um estilo formal, de prestígio e ser utilizada, geralmente, nos meios de comunicação nacional, nas escolas ou no ensino da língua a estrangeiros.

\footnotetext{
${ }^{5}$ De acordo com Mattos e Silva (1995), as normas sociais são normas que definem grupos sociais que constituem a rede social de uma sociedade. Estas normas podem ser classificadas em: normas com prestígio social, equivalente ao que se denomina norma culta, quando o grupo de prestigio é constituído por falantes de nível superior, de ambiente urbano e da classe dominante; e, normas sem prestígio social ou estigmatizadas, associadas a grupos de falantes com baixo nível educacional, de região rural e de classe social baixa.

${ }^{6}$ Citação original: "Parece lógico entonces que existan diferencias de comportamiento también dentro de una entidad nacional o lingüística y similaridades de comportamiento entre dos miembros de dos entidades vecinas. Las fronteras de un ámbito cultural no son claras ni están fijadas una vez por todas. Dentro de un determinado grupo puede haber comportamiento común en un campo (por ejemplo: lengua) y comportamientos diferentes en otro (por ejemplo, formas de cortesía), como por ejemplo el caso de Alemania y de Austria." (NORD, 1994, p. 106)
} 
Travaglia (2013, p. 158) discorre sobre as escolhas do tradutor ao deparar-se com um texto no qual seu estilo contemple um registro ou uma variedade linguística específica. Nesse caso, a autora pontua três opções: a) usar a mesma variedade de língua; b) usar outra variedade de língua; e, c) buscar vocábulos correspondentes em termos de variedade. Em relação à primeira opção, a autora afirma ser uma possibilidade mais teórica do que prática ao tradutor, uma vez que duas línguas, diferentes entre si, não terão os mesmos dialetos. Sobre a segunda opção, o tradutor deve ter cuidado ao escolher uma variedade com valor aproximado ao do TB. Este fato recai na terceira opção, embora, a autora explique que é mais fácil encontrar estruturas correspondentes em dialetos definidos por classe social, idade, sexo, modo e formalidade, função e geração, do que em dialetos de definição geográfica. A autora ressalta, ainda, que as correspondências e semelhanças entre registros e dialetos não serão fixas, imutáveis, posto que estão sujeitas à leitura ou às leituras do tradutor. E, podemos acrescentar que, no marco da tradução funcional, estarão sujeitas ao encargo tradutório.

Para Mayoral (1998), muitos estudos sobre tradução trataram do problema da variação linguística com ênfase na tradução de dialetos. Entretanto, quando se trata de tradução de variantes concretas ora falam de forma insuficiente ora tecem simples considerações sobre o estilo. O autor deixa claro que a tradução da variação linguística é um processo de tradução de seus elementos marcadores, tanto os percebidos pelo receptor como norma-padrão quanto os percebidos como marcados. Para o autor, os marcadores são pistas de contextualização (informações de parâmetros sociolinguísticos) da variação linguística convencionalizada. Portanto, no processo de tradução da variação, o tradutor deve ter em mente que o receptor percebe a variação, muitas vezes, por analogia ou contraste com as suas próprias formas de falar e a sua identidade e, nessa questão, entram em jogo os estereótipos linguísticos e culturais. Conforme o autor, na hora de traduzir, o tradutor busca soluções econômicas e de fácil processamento, fato que resulta, geralmente, na reprodução de estereótipos linguísticos, que podem não possuir relação com a realidade, mas que estão convencionalizados socialmente.

A partir do que foi exposto, verificamos que, na atividade tradutora, os estudos sociolinguísticos podem auxiliar o tradutor a lidar com marcas dialetais, mudança ou alternância de código e registro. Dessa maneira, na tradução funcional, tais estudos podem proporcionar maior compreensão do valor social de determinada variante e possibilitam uma escolha linguística adequada para que o TM cumpra seu encargo de tradução na cultura meta. Assim, ao usar atividades com a tradução funcional, no contexto de ensino-aprendizagem de 
LE, é possível aproveitar-se desta relação entre os estudos sociolinguísticos e a tradução para a conscientização de alunos brasileiros aprendizes de espanhol acerca da variação linguística, como propõe Pontes (2014).

Partindo deste pressuposto, a seguir discorremos sobre a potencialidade da tradução funcionalista do gênero textual peça teatral para o ensino da variação linguística em espanhol, e, posteriormente, descrevemos o procedimento de uma sequência didática com o uso da tradução funcionalista para o ensino de um caso concreto de variação linguística: o uso das formas de tratamento pronominais para $2^{\mathrm{a}}$ pessoa da língua espanhola.

\section{A potencialidade da tradução funcionalista de peças teatrais para o ensino da variação linguística na língua espanhola}

De acordo com Travaglia (2013, p.77), as abordagens mais modernas nos Estudos da Tradução partem do princípio de que não se traduz uma língua, mas textos. Desta forma, a autora propõe que a tradução seja um processo de retextualização, isto é, ao traduzir "O tradutor recoloca em texto numa outra língua a reconstrução de um sentido que faz a partir de uma textualização anterior" (TRAVAGLIA, 2013, p. 80, grifos da autora). Neste sentido, o tradutor estará acionando todos os elementos que conferem textualidade a um texto e que foram utilizados pelo produtor do texto original, com a especificidade de que, manejando uma outra língua, ele estará, também, trabalhando com os mesmos ou outros elementos sob perspectivas diferentes. Nesta perspectiva, Demétrio (2014, p.66), também, concebe o processo tradutório como uma retextualização, pontuando que o tradutor executa movimentos que se assemelham aos de um produtor/escritor de um texto. Ela explica que o modelo de análise pré-tradutória de Nord (2012) contempla todos os elementos de textualidade propostos por Beaugrande e Dressler (1981) e Cassany (2000), tais como: intencionalidade, aceitabilidade, intertextualidade, informatividade, coerência, coesão, adequação e correção gramatical. Portanto, se ao elaborar uma tradução, por conseguinte, produzimos um texto, empreendemos uma prática de linguagem por meio de um determinado gênero textual, sendo viáveis atividades de tradução em forma de Sequências Didáticas (SD) para o desenvolvimento de práticas de linguagem e o domínio de gêneros textuais, conforme propomos na próxima seção.

Na Tradução Funcionalista, o texto é entendido como um evento comunicativo, o qual está localizado em tempo e lugar e possui, pelo menos, dois interlocutores em condições 
apropriadas e dispostos a se comunicar para alcançar um objetivo concreto. Nas palavras de Nord (2012, p. 13):

Comparada com outras situações comunicativas, a translação é específica pelo fato de que há duas culturas (e línguas) envolvidas. A transmissão da mensagem entre o emissor (aqui: E-TB) ou autor (A-TB) e o receptor (neste caso: R-TM) se efetiva empregando dois códigos e não um, e parece interrompida pela intervenção do iniciador e do tradutor/intérprete. No entanto, tanto o TB como o TM são textos em toda a regra, integradas em uma situação comunicativa e que fazem parte, cada um, do que Beaugrande/Dressler (1981, xii) chamam um "acontecimento comunicativo". (tradução nossa) ${ }^{7}$. (NORD, 2012, p.13)

Para a autora, a correlação entre a função textual e a estrutura textual não é uma relação unívoca, uma vez que os elementos estruturais costumam ser plurifuncionais. Portanto, normalmente, um texto com uma função particular se caracteriza pela combinação de elementos típicos, tanto de caráter pragmático-situacional quanto linguísticos. Por conta disso, Nord reconhece que o estudo e o agrupamento de gêneros, tipos e classes de textos, de acordo com suas características típicas, contribui ao trabalho do tradutor. Pois, a relação entre a configuração estrutural e a função textual varia, a partir das normas e convenções culturais.

Neste contexto, ao considerar a configuração estrutural e a função textual na situação comunicativa, a autora não trata de texto (no sentido estritamente linguístico), mas de gêneros textuais, entendidos neste trabalho como: "o reflexo de estruturas sociais recorrentes e típicas de cada cultura” (MARCUSCHI, 2010, p. 34).

Segundo Nord (2012, p. 21), os gêneros textuais permitem ao tradutor antecipar certas características intratextuais típicas e se as informações extratextuais de um TB são escassas, através do gênero, é possível ter uma base para interpretar as características intratextuais no que diz respeito à sua funcionalidade. Outrossim, reconhecer a que gênero pertence o TB pode ter impacto tanto na sua recepção quanto na produção do TM, além de poder implicar no reconhecimento da intenção do autor. Visto que há textos que são utilizados em situações padronizadas sempre para as mesmas funções (meteorológico, oração, manual de instrução) e

\footnotetext{
${ }^{7}$ Comparada con otras situaciones comunicativas, la traslación es específica por el hecho de que hay dos culturas (y lenguas) implicadas. La transmisión del mensaje entre el emisor (aquí: E-TB) o autor (A-TB) y el receptor (en este caso: R-TM) se efectúa empleando dos códigos y no uno, y parece interrumpida por la intervención del iniciador y del traductor/intérprete. No obstante, tanto el TB como el TM son textos en toda la regla, integradas en una situación comunicativa y que forman parte, cada uno, de lo que de Beaugrande / Dressler (1981, xii) llaman un "acontecimiento comunicativo". (NORD, 2012, p. 13)
} 
estas situações resultam em determinada convenção sobre as intenções do emissor ou autor do texto, para além do tipo de receptor. Nesta perspectiva, notamos que o texto não pode ser compreendido ou isolado de sua situação ou prática comunicativa. Portanto, mais do que lidar com sequências linguísticas ou composicionais (aspectos lexicais, sintáticos, etc.), o tradutor lida com gêneros textuais, para os quais, como assevera Marcuschi (2010, p. 23):

Usamos a expressão gênero textual como uma noção propositalmente vaga para referir os textos materializados que encontramos em nossa vida diária e que apresentam características sociocomunicativas definidas por conteúdos, propriedades funcionais, estilo e composição característica. Se os tipos textuais são apenas meia dúzia, os gêneros são inúmeros.

Este autor parte do princípio básico de que é impossível se comunicar verbalmente a não ser por algum gênero, assim como é impossível não fazê-lo por meio de um texto. Desta forma, o gênero está entre o texto (fenômeno linguístico observável) e o discurso (aquilo que um texto produz ao se manifestar em uma instancia discursiva, tal como a jurídica, a jornalística, a religiosa, etc.), sendo entendido como prática social e prática textual-discursiva.

Marcuschi (2010), ao buscar descrever o que é um gênero textual, afirma seguir a posição defendida por Bakhtin (1997) e Bronckart (1999) ao tratar a língua em seus aspectos discursivos e enunciativos, não restringindo a língua apenas as suas peculiaridades formais. Para estes autores, a língua é uma atividade social, histórica e cognitiva, logo, privilegiam a natureza funcional e interativa e não o aspecto formal e estrutural da língua. Neste sentido, o autor segue a perspectiva sociointerativa da língua e, nesse contexto: "os gêneros textuais se constituem como ações sociodiscursivas para agir sobre o mundo e dizer o mundo, constituindoo de algum modo" (MARCUSCHI, 2010, p. 23).

Ainda, sobre os gêneros textuais, Marcuschi (2010) explica a diferença entre "tipo textual" e "gênero textual", já que em muitos materiais de ensino há confusão no emprego destes termos. O primeiro constitui uma espécie de sequência teoricamente definida pela natureza linguística de sua composição (aspectos lexicais, sintáticos, tempos verbais) e as categorias mais conhecidas são: narração, argumentação, exposição, descrição e injunção. Enquanto o segundo, refere-se a textos materializados ou empíricos que encontramos em nossa vida diária, portanto, para a noção de gênero textual predominam os critérios de ação prática, circulação sócio histórica, funcionalidade, conteúdo temático, estilo e composicionalidade. 
Deste modo, em um gênero textual, realiza(m)-se um ou vários tipos textuais, caracterizado(s) por uma heterogeneidade tipológica. Por exemplo, no gênero textual peça teatral, há sequências tipológicas descritivas e expositivas (ao apresentar as personagens ou descrever o ambiente das cenas), argumentativas (no diálogo entre as personagens) ou injuntiva (ao ordenar), entre outros.

Tendo em vista o processo de ensino-aprendizagem dos gêneros textuais, Dolz e Schneuwly (1996) entendem o gênero como um megainstrumento para agir em situações de linguagem e propõem que tais gêneros são introduzidos em nossas experiências e consciência mediante três fatores: práticas de linguagem, capacidades de linguagem e as estratégias de aprendizagem. Segundo Pinto (2010, p. 53), é por meio das “práticas de linguagem”, isto é, das mediações comunicativas, cristalizadas em forma de gêneros, que as significações sociais são construídas. Logo, ao interagir em uma prática de linguagem, o indivíduo utiliza-se das “capacidades de linguagem", que são os conhecimentos necessários para a produção e a compreensão de um gênero textual em uma determinada situação comunicativa. Essas capacidades de linguagem, de acordo com Dolz e Schneuwly (1996), podem ser subdivididas em: 1. Capacidades de ação, que se relacionam com o contexto de produção da ação de linguagem e a sua adequação ao ambiente físico, social e subjetivo; 2. Capacidades discursivas, que se relacionam às escolhas no nível discursivo e a infraestrutura geral do texto, plano geral, tipos de discurso e sequências; e, 3. Capacidades linguístico-discursivas, que tratam dos mecanismos de textualização, operações de conexão e segmentação, coesão nominal e verbal, mecanismos enunciativos (gerenciamento de vozes e modalizações), construção de palavras e enunciados e escolhas lexicais. A seguir, apresentamos a descrição de tais capacidades de linguagem, a partir de Stutz e Cristóvão (2011): 


\section{CAPACIDADES DE AÇÃO}

(1CA) Realizar inferências sobre: quem escreve o texto, para quem ele é dirigido, sobre qual assunto, quando o texto foi produzido, onde foi produzido, para que objetivo; (2CA) Avaliar a adequação de um texto à situação na qual se processa a comunicação;

(3CA) Levar em conta propriedades linguageiras na sua relação com aspectos sociais e/ou culturais; (4CA) Mobilizar conhecimentos de mundo para compreensão e/ou produção de um texto.

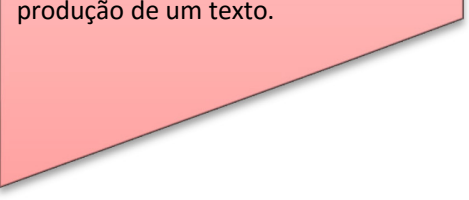

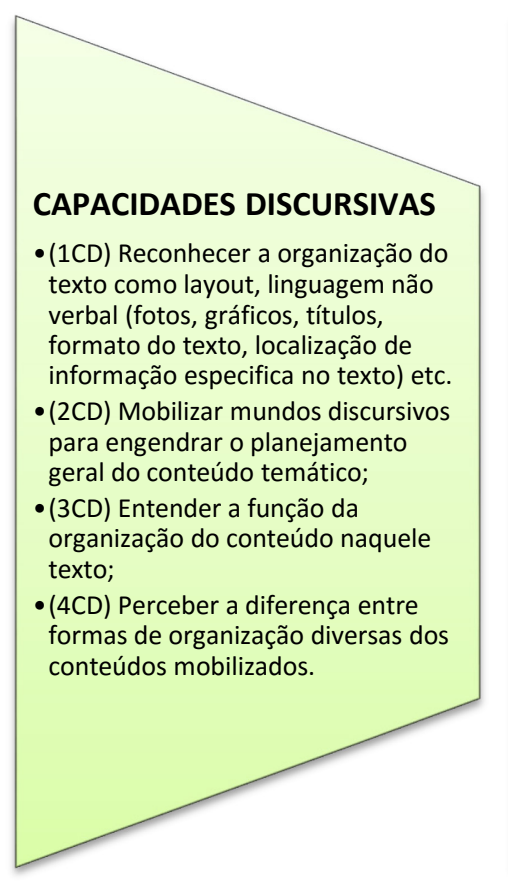

CAPACIDADES LINGUÍSTICODISCURSIVAS

- Constroem sentido mediante representações sobre as operações de textualização, de construção de enunciados e da escolha do vocabulário. Os conhecimentos a serem abordados referem-se à microestrutura (as unidades linguísticas das frases e sentenças) como: coesão, conexão verbal, conexão

Figura 1. Descrição das capacidades de linguagem por Stutz e Cristóvão (2011).

Fonte: adaptado de Stutz e Cristóvão (2011).

Apesar desta divisão, as capacidades não operam de forma compartimentada ou linear. Sobre o seu conhecimento e domínio, Lugli (2013, p. 39) afirma que são indispensáveis ao ensino de línguas, visto que, ao interagir por meio de textos nas diferentes situações sociais, utilizamos tais capacidades. É por meio da interação que os aprendizes se conscientizam das habilidades e capacidades para agir nas práticas de linguagem, internalizando e estruturando as suas próprias estratégias de aprendizagem. Neste sentido, ao ensinar a língua, através de gêneros textuais, é necessário realizar a transposição didática do gênero escolhido. Para tanto, conforme Cristóvão (2010, p.107), é preciso conhecer os elementos ensináveis do gênero, isto é, o que pode ser objeto de ensino-aprendizagem dentro de uma determinada situação comunicativa. Assim, para realizar o estudo do gênero, a autora propõe a análise de um corpus de textos pertencentes ao gênero determinado com vistas à construção de um "modelo didático", o qual, com base em Dolz e Schneuwly (1998), deve ser construído a partir dos seguintes elementos: (i) os resultados de aprendizagem expressos por documentos oficiais de ensino e da determinação das capacidades reveladas pelos alunos; (ii) os conhecimentos dos experts na produção do gênero em foco e dos conhecimentos linguísticos já elaborados sobre ele; e, (iii) as capacidades de linguagem dos alunos. 
Sobre os elementos constituintes do modelo didático do gênero, apresentamos os conhecimentos dos experts na produção do gênero, já que os resultados de aprendizagem expressos por documentos oficiais e as capacidades de linguagem dos aprendizes dependerão de um contexto de ensino específico. Deste modo, sobre o gênero peça teatral, Granero (2011) pontua que: "A arte, e consequentemente o teatro, fazem parte da linguagem e da cultura próprias de um povo e são peças essenciais para a compreensão de sua história." (GRANERO, 2011, p.13). A autora expõe que o uso do teatro em aulas de LE auxilia aos alunos no uso da língua de uma maneira mais natural, desinibida e criativa, pois um recurso simples de representação de diálogos serve para dar uma dimensão real e pragmática aos atos de fala que se aprendem, no decorrer do curso. A autora, também, apresenta um breve percurso histórico acerca do teatro, o qual apresentamos no seguinte esquema:

A Tragédia Grega - apresentavam-se nos "ditirambos", festivais de teatro, à época de Dionísio. Alguns autores são: Ésquilo (525-456, a.C.), Sófocles (496-406 a.C.) e Aristóteles (384-322). Através do teatro, exprimia-se o pensamento grego, suas reflexões e mitos.

O Teatro Clássico - estava sujeito ás normas ditadas por Aristótoles e nele o discurso teatral valorizava a narrativa. Busca da harmonia das personagens e a verossimilhança, além de seguir as seguintes regras: a ação deve se referir à ação de um único herói e deve construir um todo; a unidade de tempo referente as peripécias do herói não deve ultrapassar 24 h; a unidade de lugar deve centrar-se em um pequeno espaço. Embora nem todos os autores seguissem à risca tais regras.

Teatro dos Séculos XVIII e XIX - ocorrem renovações cênicas e inicia-se um relativo afastamento das regras do Classisimo ao eliminar os diálogos em verso e resgatar as personagens do cotidiano, como o "artesão", "o homem do povo", e os "burgueses". As personagens falam com uma linguagem popular, familiar. A tragédia é substituída pelo drama burguês.

Teatro do Século XX aos dias atuais - presença da estética simbolista (liberdade criativa, distanciamento da realidade); maior relação entre canto e música na representação artística, espaço cênino menos excessivo e mais vazio, importancia da iluminação, busca de uma unidade estética,

Figura 2. Breve histórico do teatro com base em Granero (2011).

Fonte: Adaptado de Granero (2011).

Para Ubersfeld (2005), o teatro é a um só tempo produção literária e representação concreta, por sua vez, Ryngaert (2005) explicita que o texto de teatro tem o bizarro estatuto de uma escrita destinada a ser falada. Assim, neste gênero, há uma relação complexa entre a oralidade e a escrita, fato que pode ser explorado uma vez que Marcuschi (2010, p.35) salienta a pertinência de se ter em mente a relação entre o oral e o escrito, no estudo dos gêneros textuais. Sobre a constituição deste gênero textual, encontramos uma organização tipográfica própria na 
qual, segundo Ubersfeld (2005) e Ryngaert (1995), há dois grandes elementos que a constituem: a didascália e o diálogo. A primeira trata das partes do texto que não se destinam a ser pronunciados no palco, mas que ajudam ao leitor compreender e imaginar o espaço em que ocorre as cenas e as ações das personagens. A didascália é a responsável por descrever o contexto de comunicação e possui marcas tipográficas específicas, tais como parênteses, colchetes ou letras itálicas. Logo, fazem parte da didascália: o nome das personagens (em lista inicial e no decorrer dos diálogos); as indicações cênicas ao longo dos diálogos; a descrição das cenas no início de atos, quadros, cenas ou fragmentos.

Por outra parte, o diálogo se constitui das falas das personagens, podendo encadear-se de modo cerrado (princípio das falas alternadas) ou manifestar uma evidente desigualdade na extensão dos discursos. Os grandes "blocos" de textos assinalam as tiradas, isto é, os longos discursos de uma personagem sem a interrupção de outras personagens, ou os monólogos. (RYNGAERT, 1995, p. 43). A fala das personagens, no texto, pode apresentar-se em verso ou em prosa. Por conta disso, Ubersfeld $(2005$, p. 7) chama a atenção sobre a distinção linguística entre a didascália e o diálogo que, para a autora, está relacionada com a enunciação, há, portanto, na didascália a fala do autor e no diálogo a fala das personagens. Este fato é relevante, posto que, por este motivo, o texto teatral não pode ser entendido como uma confidência, expressão de personalidade ou problemas do autor, já que os aspectos subjetivos estão expressamente remetidos a outros locutores.

No que se refere às grandes partes das peças teatrais, na concepção de Ryngaert (1995), a maioria das peças teatrais está organizada em diferentes partes e o seu modo de organização remete a uma determinada estética. Tradicionalmente, há os atos e cenas, os quais, nas tragédias, distribuíam-se em cinco atos e nas comédias em três atos. Os atos podem ser divididos em cenas, de acordo com a entrada e a saída de personagens, que podem ser divididos em quadros, segundo uma concepção pictórica de atmosferas diferenciadas das cenas. $\mathrm{Na}$ prática moderna, o autor ressalta que, inspirados nos cinemas, os autores teatrais falam de sequências, fragmentos, movimentos (em referência às obras musicais) e pedaços, jornadas e partes que, às vezes, possuem títulos próprios. (RYNGAERT, 1995, p. 38). Esta divisão da peça teatral, também, implica na decupagem, isto é, na forma de apreender o real. Ela organiza as ações e dá ritmo ao texto.

As peças teatrais, também, são consideradas obras literárias e de ficção. Por isso, apresentam componentes narrativos, tais como: o enredo, o espaço, o tempo e as personagens. 
Tradicionalmente, a narrativa, na peça teatral, está dividida em: uma exposição (compreensão da ação, personagens e assunto); um nó (obstáculos e contrariedades na ação, constituindo conflitos, peripécias) e desfecho (a eliminação dos obstáculos e problemas desenvolvidos nos acontecimentos). $\mathrm{O}$ enredo, em uma peça teatral, é construído e apresentado através das ações realizadas pelas personagens; o tempo e o espaço são identificados tanto nas didascálias quanto nas falas das personagens, através de marcadores temporais, advérbios de lugar, etc. As personagens possuem papel central no texto teatral, já que é por suas ações e discursos que identificamos todas as características do enredo. Há, também, pistas textuais acerca do tempo e do espaço, além da própria caracterização das personagens.

Ubersfeld (2005, p.174) esclarece que toda personagem, no teatro, produz a linguagem da classe social a que pertence. Porém, não a reproduz com exatidão referencial. Assim, a autora pontua que o idioleto das personagens, geralmente, ao utilizar particularidades linguísticas (representações da língua popular), busca caracterizar aquele que está fora do grupo e objetiva, ainda, provocar o riso, ao representar, por exemplo, personagens estrangeiras ou populares, que não sabem utilizar a língua de outras personagens cultas. Já o discurso, no teatro, está centrado na enunciação, é um discurso do eu/tu e do aqui/agora. (UBERSFELD, 2005, p.175)

Tal uso das variedades linguísticas, no discurso teatral, possibilita a reflexão linguística acerca do fenômeno de variação linguística, principalmente, nas comédias. Neste viés, Mambrini (2004) ressalta o uso da linguagem popular, na caracterização de personagens nos textos teatrais, como fonte de pesquisa variacionista. Assim, no que tange à tradução destes textos, Briguglia (2006, p.34) salienta a importância de se compreender a função da variação no texto original para buscar uma solução de tradução adequada, e assevera que, neste caso, a tradução funcional de peças teatrais pode auxiliar o tradutor (ou aprendiz) na escolha da variante mais adequada para o TM.

Em forma de resumo, tendo em vista o que os autores elencam sobre o gênero, elaboramos o seguinte quadro geral com as principais características do gênero textual peça teatral de comédia: 
Quadro 2. Características gerais do gênero peça teatral de comédia com base na literatura.

\begin{tabular}{|c|c|c|c|c|c|c|c|}
\hline Gênero & Objetivo & $\begin{array}{c}\text { Plano } \\
\text { textual } \\
\text { global }\end{array}$ & $\begin{array}{c}\text { Tipo de } \\
\text { discurso e } \\
\text { de } \\
\text { sequência }\end{array}$ & $\begin{array}{c}\text { Coesão } \\
\text { nominal }\end{array}$ & $\begin{array}{c}\text { Coesão } \\
\text { verbal }\end{array}$ & Vozes & $\begin{array}{c}\text { Escolha } \\
\text { lexical }\end{array}$ \\
\hline $\begin{array}{c}\text { Peça } \\
\text { teatral de } \\
\text { comédia }\end{array}$ & $\begin{array}{l}\text { Provocar } \\
\text { riso nos } \\
\text { espectado- } \\
\text { res, através } \\
\text { de situa- } \\
\text { ções cômi- } \\
\text { cas, carac- } \\
\text { terização de } \\
\text { tipos e de } \\
\text { costumes ou } \\
\text { absurdo da } \\
\text { história. }\end{array}$ & $\begin{array}{l}\text { Título da } \\
\text { obra, lista } \\
\text { de } \\
\text { personagens } \\
\text {, divisão } \\
\text { textual em } \\
\text { três ou mais } \\
\text { atos com } \\
\text { duas ou } \\
\text { mais cenas } \\
\text { ou quadros. }\end{array}$ & $\begin{array}{l}\text { Sequências } \\
\text { dialogais ou } \\
\text { conversacio } \\
\text { nais entre as } \\
\text { personagens } \\
\text {; sequencias } \\
\text { descritivas, } \\
\text { nas } \\
\text { didascálias. } \\
\text { Predomínio } \\
\text { de frases } \\
\text { exclamati- } \\
\text { vas e inter- } \\
\text { rogativas. }\end{array}$ & $\begin{array}{l}\text { Anáforas } \\
\text { pronominai } \\
\mathrm{s} \\
\text { nominais. } \\
\text { Dêixis de } \\
\text { pessoa por } \\
\text { meio dos } \\
\text { pronomes } \\
\text { de } \\
\text { tratamento. }\end{array}$ & $\begin{array}{l}\text { Predomí- } \\
\text { nio de } \\
\text { verbos no } \\
\text { presente do } \\
\text { indicativo, } \\
\text { Verbos no } \\
\text { gerúndio } \\
\text { (didascá- } \\
\text { lias), Impe- } \\
\text { rativos. }\end{array}$ & $\begin{array}{l}\text { Das } \\
\text { persona- } \\
\text { gens, nos } \\
\text { diálogos e } \\
\text { do autor, } \\
\text { nas } \\
\text { didascálias }\end{array}$ & $\begin{array}{l}\text { Diversificad } \\
\text { o, Nomes } \\
\text { próprios, } \\
\text { adjetivos, } \\
\text { léxico } \\
\text { popular }\end{array}$ \\
\hline
\end{tabular}

Na próxima seção, exemplificamos o projeto inicial de uma sequência didática com a tradução do gênero textual peça de teatro com um foco na abordagem da variação linguística nas formas de tratamento para a $2^{\mathrm{a}}$ pessoa em diferentes países falantes de língua espanhola.

\section{Sequência didática com o uso da tradução: possibilidades para o ensino da variação linguística nas formas de tratamento do espanhol}

Uma sequência didática (SD) consiste em: “[...] um conjunto de atividades escolares organizadas, de maneira sistemática, em torno de um gênero textual oral ou escrito" (DOLZ, NOVERRAZ, SCHNEUWLY, 2004, p. 96) Para os autores, quando nos comunicamos, adaptamo-nos à situação comunicativa e, quando interagimos em situações parecidas, escrevemos/falamos textos com características semelhantes, os quais são considerados gêneros textuais, "conhecidos de e reconhecidos por todos, e que, por isso, facilitam a comunicação" (DOLZ; NOVERRAZ; SCHNEUWLY, 2004, p. 97). Assim, o objetivo de uma SD centra-se em proporcionar ao aprendiz o domínio de um gênero textual, permitindo-lhe que escreva ou fale de uma maneira mais adequada numa dada situação comunicativa. Neste sentido, a estrutura base de uma SD é apresentada pelos autores da seguinte forma: 


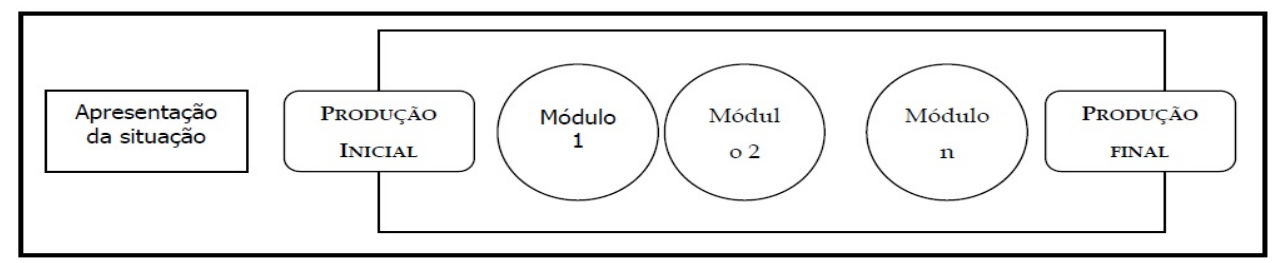

Esquema da seqüência didática

Figura 3. Esquema da SD proposto por Dolz, Noverraz e Schneuwly (2004). Fonte: Dolz, Noverraz e Schneuwly (2004, p. 97).

Observa-se, na imagem acima, que a primeira etapa de uma SD é a apresentação de uma situação comunicativa, na qual é feita uma contextualização da prática de linguagem a ser empreendida e há a exposição de uma motivação para a produção de um gênero textual. Nas palavras dos autores, na prática de uma SD: "O aluno deve aprender que escrever é (também) reescrever. A estruturação da SD em primeira produção, por um lado, e produção final, por outro, permite tal aprendizagem" (DOLZ; NOVERRAZ; SCHNEUWLY, 2004, p.113). Diante deste contexto, é possível realizar uma SD com o uso da tradução funcionalista, já que no processo tradutório circular, proposto por Nord (2012), o tradutor/aprendiz está frequentemente analisando o TB, verificando as condições de produção do TM e o produzindo. Pois, para alcançar um TM funcional ao seu encargo de tradução, tem que escrever várias versões preliminares do TM.

Além disso, no âmbito do Ensino de Línguas, uma SD com o uso da tradução funcionalista pode ser produtiva ao aprendizado linguístico-cultural, uma vez que o aprendiz estará frequentemente contrastando e comparando vários aspectos das línguas e culturas envolvidas na tradução. Sobre esta possibilidade, Beato-Canato e Cristóvão (2014, p. 218) reconhecem que a comparação entre as línguas pode ser um recurso de mútua ajuda, por exemplo, ao comparar pronomes, advérbios e expressões de opinião, embora apontem que esta comparação deve ir além do aspecto formal, visando estabelecer relações mais conscientes acerca da função comunicativa desses elementos no texto. Isto pode ser alcançado com a tradução, em uma perspectiva funcional, assim como atestam Barrientos (2014), Demétrio (2014) e Laiño (2014).

No caso de uma SD com a tradução funcionalista, a etapa de apresentação da situação inicial pode constituir-se de amostras de traduções do gênero determinado que circulam socialmente, além da apresentação de um texto a ser traduzido e um encargo de tradução didático (situação comunicativa que exige a tradução). O encargo de tradução, conforme 
Nord(1996), deve conter: (i) a função ou funções comunicativas que a tradução deve alcançar, (ii) especificar os destinatários do texto, além das condições temporais e locais previstas para a recepção da tradução, (iii) o meio pelo qual será transmitida e o motivo pelo qual se produz a tradução. Sobre esta fase inicial, Laiño (2014, p. 99) não define um encargo de tradução didático, mas propõe a elaboração de um projeto de tradução a ser desenvolvido individualmente pelos aprendizes, apenas definindo a nacionalidade do público meta (brasileiro) e do texto base, publicidades argentinas. Assim, os estudantes ficam livres para manter, mudar e/ou adaptar aspectos do TM, analisando o seu receptor e o produtor do TB. A autora relaciona este processo de especificação do projeto de tradução à etapa de planejamento da escrita, proposta por Cassany (2010), pois ambos ocorrem antes da elaboração do texto.

A partir desta primeira etapa, inicia-se a produção inicial, a qual será entendida como um diagnóstico acerca do domínio do gênero textual pelos alunos e de suas capacidades de linguagem (BARROS, 2012, p. 82). Esta produção inicial, na SD com a tradução funcionalista, será baseada em uma análise do TB a partir do modelo de análise pré-tradutória de Nord (2012), o qual permite analisar as características intra e extratextuais do TB e do TM, mediante um encargo de tradução determinado, ou um projeto de tradução como realizou Laiño (2014). Este modelo de análise possibilitará ao aprendiz examinar os elementos que devem ser adaptados à cultura do receptor do TM e, com estas informações, produzir uma primeira produção do TM. Ao utilizar o modelo de análise pré-tradutório (apresentado anteriormente), será possível, também, a integralização das capacidades de linguagem, conforme demonstramos no esquema na próxima página (Figura 4).

Esta etapa da análise pré-tradutória de Nord (2012) antes da primeira produção, coincide com o que Costa-Hürbes e Simioni (2014, p. 26) chamam de Módulo de Reconhecimento, uma adaptação do esquema de SD suíço à vertente brasileira. Nesta etapa, as autoras definem que é feita uma pesquisa, leitura e análise linguística do gênero a ser produzido, aspectos proporcionados pelo modelo de análise da Nord (2012). Com base nas dificuldades apresentadas pelos alunos, ao realizarem a primeira produção do gênero textual em uma SD, são elaborados os módulos. Estes, segundo Cristóvão (2009, p.310), dependem das capacidades dos alunos, do nível escolar, do currículo e do gênero trabalhado. Não há uma quantidade limite de módulos que possam ser realizados em uma SD, podendo variar de acordo com o contexto de ensino, disponibilidade de tempo, objetivos da SD, etc. Ainda, para Barros (2012, p.82), os módulos devem abordar problemas de diferentes níveis (apresentação da situação de 
comunicação, aprofundamento temático, infraestrutura do gênero, etc.), além de atividades e exercícios variados.

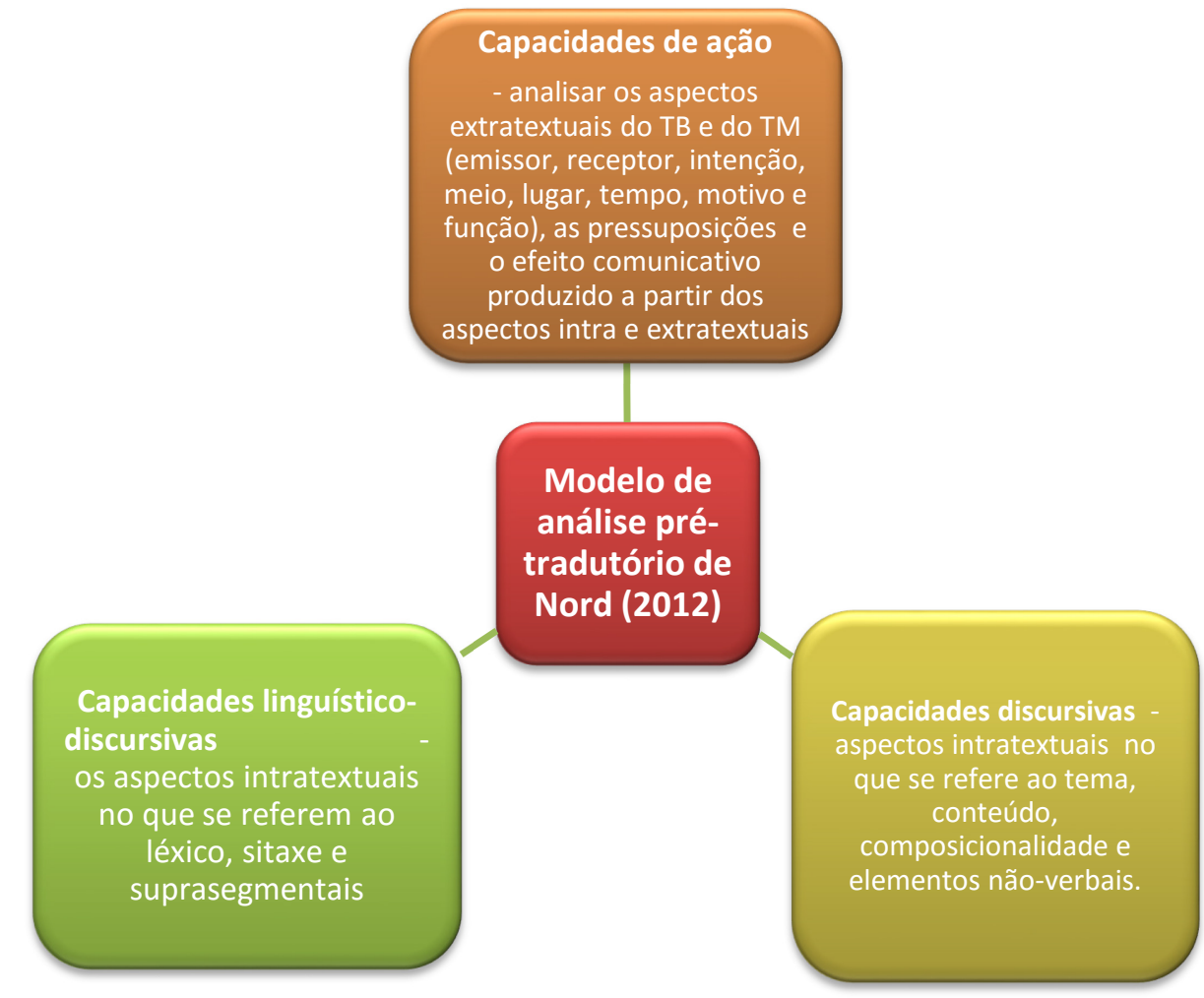

Figura 4. As capacidades de linguagem dentro do modelo de análise textual pré-tradutória de Nord (2012)

Fonte: autoria própria.

No caso dos módulos de uma SD com o uso da tradução funcionalista, estes serão baseados nas dificuldades apresentadas pelos aprendizes, durante a análise textual prétradutória de Nord (2012), e na primeira produção do TM. Assim, se, por exemplo, os aprendizes mostrarem dificuldades no que tange à identificação da composicionalidade do TB e TM, elaborar-se-ão módulos específicos sobre o gênero textual que está sendo traduzido. Ou, ainda, se os aprendizes mostrarem dificuldades na adequação linguística do TM ao público meta do encargo de tradução, planejar-se-ão módulos específicos acerca dos aspectos linguísticoculturais relacionados a tal adequação. É salutar explicitar, também, que em tais módulos as capacidades de linguagem devem ser abordadas de forma proporcional e integrada. Além disso, conforme a adaptação do esquema da SD à realidade brasileira dos anos iniciais de ensino, proposta por Costa-Hürbes e Simione (2014), há a possibilidade da realização de módulos sobre o reconhecimento do gênero antes mesmo da primeira produção. Ao incluir esta sugestão, 
poderemos propiciar aos alunos maiores condições de reconhecimento das características peculiares do gênero e de sua funcionalidade.

Após a execução dos módulos, propõe-se uma produção final, a qual, nas palavras de Cristóvão (2009, p. 311): "se caracteriza como o lugar de integração dos saberes construídos e de instrumentos apropriados". Esta produção final, no que se refere ao trabalho do professor, pode ser comparada à primeira produção, o que permitirá ao professor uma avaliação do desenvolvimento real do aluno e uma avaliação formativa. (BARROS, 2012, p. 82). Assim, em relação à SD com o uso da tradução funcionalista, será proposta uma reescrita da primeira produção, que constituirá a versão final. Logo, espera-se que tal produção final seja funcional na situação-em-cultura, determinada no encargo de tradução didático, proposto para a SD. A tradução final, também, pode passar por um último processo de revisão ou reescrita antes de sua circulação social. (BARROS, 2012, p. 82). Esta circulação social do gênero é outra adaptação proposta por Costa-Hürbes e Simione (2014, p. 27), no esquema da SD, consistindo em um momento de garantia e efetivação do uso real da linguagem. Nesta etapa, o texto produzido será compartilhado com seus interlocutores, conforme previsto inicialmente na apresentação da situação comunicativa, isto é, no encargo de tradução.

Do discorrido até agora, temos subsídios para afirmar que o procedimento de uma SD, a partir da tradução funcionalista de gêneros textuais, é viável para o contexto de Ensino de Línguas. Neste sentido, retomando a aproximação entre a atividade tradutória e o conhecimento da variação linguística, especificado anteriormente, propomos a elaboração de uma SD com o gênero textual peça teatral de comédia, enfocando a variação no uso das formas de tratamento da língua espanhola para alunos brasileiros. Tendo em vista a complexidade da variação linguística deste fenômeno no mundo hispânico (FONTANELLA DE WEINBERG, 1999; CALDERÓN CAMPOS, 2010), sua abordagem superficial em materiais didáticos de espanhol utilizados no Brasil (NASCIMENTO, 2007; BRASIL, 2014), além da pertinência de seu conhecimento desde os níveis iniciais de aprendizagem.

Na concepção de Cristóvão (2009, p.323), o ideal para o trabalho com SD são textos sociais, isto é, textos oriundos de contextos sociais reais. Por isso, propomos que a seleção da(s) peça(s) de teatro se dê a partir dos seguintes critérios:

1. peças teatrais de diferentes países hispânicos, apresentando casos de variação linguística nas formas de tratamento para $2^{\mathrm{a}}$ pessoa (Caso se proponha uma tradução direta); 
2. peças teatrais de origem brasileira, de distintas regiões, apresentando casos de variação linguística nas formas de tratamento para $2^{\mathrm{a}}$ pessoa (Caso se proponha uma tradução inversa);

3. período histórico dos textos;

4. gênero comédia;

5. extensão da obra teatral;

6. disponibilidade em ambiente virtual.

O primeiro critério pode selecionar peças de acordo com a divisão dos sistemas de tratamento pronominal da língua espanhola, proposta por Fontanella de Weinberg (1999):

Quadro 3. Divisão do sistema pronominal do espanhol por Fontanella de Weinberg (1999).

\begin{tabular}{|c|c|c|c|c|c|c|c|c|c|}
\hline & \multicolumn{2}{|c|}{ Sistema I } & \multicolumn{2}{|c|}{ Sistema II } & \multicolumn{3}{|c|}{ Sis tema III } & \multicolumn{2}{|c|}{ Sis tema IV } \\
\hline & Singular & Plural & Singular & Plural & $\begin{array}{r}\mathrm{Sin} \\
\text { IIIa }\end{array}$ & $\begin{array}{l}\text { ular } \\
\text { III b }\end{array}$ & Plural & Singular & Plural \\
\hline Intimidad & \multirow{2}{*}{$t u ́$} & \multirow{2}{*}{ vosotros } & \multirow{2}{*}{$t u ́$} & \multirow{3}{*}{ ustedes } & $V O S \sim$ & vos & \multirow{3}{*}{ ustedes } & \multirow{2}{*}{ vos } & \multirow{3}{*}{ ustedes } \\
\hline Confianza & & & & & $t u$ & tú & & & \\
\hline Formalidad & usted & usted & usted & & \multicolumn{2}{|c|}{ usted } & & usted & \\
\hline
\end{tabular}

Já o segundo critério pode basear-se em Scherreet.al. (2015), que reúne diversas pesquisas sobre os sistemas de tratamento pronominal para segunda pessoa utilizados no Brasil, mapeando os usos de "tu" e "você" no país e determinando, pelo menos, a existência de 6 subsistemas, a saber:

Quadro 4. Subsistemas dos pronomes "tu" e "você" no português brasileiro com base em Scherre et.al. (2015).

Subsistema só você Uso exclusivo das variantes você/cê/ocê, ocorrendo na Região Centro-Oeste (exceto Distrito Federal); na Região Sudeste, na maior parte de Minas Gerais, Espírito Santo e São Paulo; na Região Nordeste, a capital baiana; na Região Norte, a parte central, sul e sudeste de Tocantins; e, na Região Sul, Paraná.

Subsistema mais tu Frequência do uso de "tu" acima de $60 \%$ com concordância com concordância verbal abaixo de $10 \%$. É encontrado na Região Norte, em baixa Amazonas (por exemplo, Tefé), e na Região Sul, o estado do Rio Grande do Sul (por exemplo, as cidades de Porto Alegre e Flores da Cunha).

Subsistema mais tu Uso médio de "tu" acima de 60\%, com concordância verbal com concordância alta entre $40 \%$ e $60 \%$. Este subsistema é encontrado na Região Norte, no estado do Pará (Belém e Mocajuba) e na Região Sul, no estado de Santa Catarina (por exemplo, Florianópolis).

Subsistema tu/você Uso médio de "tu" abaixo de $60 \%$ com concordância abaixo de com concordância $10 \%$. É encontrado na Região Nordeste (norte e nordeste do baixa estado do Maranhão), Norte (algumas partes de Tocantins) e Sul (nas cidades de Chapecó e Concordia, em Santa Catarina). 


\begin{tabular}{|l|l|}
$\begin{array}{l}\text { Subsistema tu/você } \\
\text { com concordância } \\
\text { média }\end{array}$ & $\begin{array}{l}\text { Uso de "tu" abaixo de 60\% com concordância verbal de } 10 \text { a } \\
39 \% \text {. Encontra-se nas regiões Norte (Manaus, Amazonas) e Sul } \\
\text { (Blumenau e Lages, em Santa Catarina), e nas capitais de } \\
\text { diversos estados nordestinos, tais como Teresina (Piauí), João }\end{array}$ \\
$\begin{array}{l}\text { Pessoa (Paraíba), Recife (Pernambuco), Fortaleza (Ceará). } \\
\text { Subsistema você/tu } \\
\text { sem concordância }\end{array}$ & $\begin{array}{l}\text { Uso de tu com 1\% a 90\% sem concordância verbal. Apresenta- } \\
\text { se na região Centro-Oeste, no Distrito Federal, e na Região } \\
\text { Sudeste, no estado do Rio de Janeiro, Santos - SP, São João da } \\
\text { Ponte- MG. Já na Região Norte, em Roraima e no Acre, e na } \\
\text { Região Nordeste, Feira de Santana, Sapé, Rio de Contas e } \\
\text { Poções na Bahia, além de Bacabal, Balsas, Ponheiro e Alto } \\
\text { Parnaíba no Maranhão. }\end{array}$ \\
\end{tabular}

O terceiro critério centra-se no período histórico das obras teatrais, posto que dependendo do período especificado, poderemos encontrar distintos usos das formas de tratamento pronominal para segunda pessoa, em ambas as línguas (espanhol e português brasileiro). Por exemplo, se as obras hispânicas escolhidas tiverem como critério o período histórico do século XV ou XVI é possível encontrar o uso das formas de tratamento "vos" e "vuestramerced" com usos que marcam distanciamento e/ou respeito para com o interlocutor. Porém, em obras do século XIX, XX ou XXI, tal uso será inexistente, visto que a forma "vuestramerced" sofreu mudanças fonéticas e até mesmo de valor, evoluindo à forma atual "usted".

Por outro lado, a forma "vos" perdeu ser valor honorífico, convertendo-se em uma forma de tratamento de intimidade e/ou informalidade em muitos países hispano-americanos. (CALDERÓN CAMPOS, 2010). De igual modo, no português brasileiro houve a evolução da forma “vossa mercê" para a forma "você", além do arcaísmo da forma "vós". Estes são aspectos que, dependendo do período da obra teatral, também, poderão ser encontrados.

Sobre os demais critérios, sugerimos que as obras sejam do gênero comédia tendo em vista que "a interdição de variedades linguísticas não-padrão ao estatuto de língua literária implica que só na paródia esse dizer tenha um lugar. Não é por acaso que os textos teatrais em que se apoia o corpus linguístico dos estudos variacionistas são sobretudo comédias". (MAMBRINI, 2004, p.28). Desta forma, ainda que a variável formas de tratamento para $2^{\circ}$ pessoa, geralmente, faça parte da variedade padrão, de acordo com a região e outros aspectos, há que levar em conta que, dentre as formas de tratamento da língua espanhola, o voseo, segundo Carricaburo (1997), pode aparecer como norma culta e geral, como regionalismo, ou como norma rural e não-padrão. 
Por outra parte, sugerimos como critério a extensão das obras, já que, geralmente, o tamanho de cada obra teatral é variável e dependendo do nível de conhecimento e leitura na LE ou LM dos alunos, as obras escolhidas para a SD podem ter maior ou menor extensão. Na perspectiva de Nord (2012, p. 160), se o texto autêntico escolhido é longo ou muito difícil, a tarefa de tradução pode ser facilitada de acordo com o seu encargo de tradução, pedindo a tradução de partes do texto, combinada com uma leitura superficial ou com um resumo do texto. Inclusive, achamos pertinente o critério de disponibilidade dos textos em ambiente virtual pela praticidade de busca de obras teatrais em bibliotecas digitais, blogs, etc., tais como: o site $\mathrm{d} a$ Biblioteca Digital de Peças Teatrais - BD Teatro, da Universidade Federal de Uberlândia; o site da Biblioteca Virtual Miguel de Cervantes e o site da Biblioteca Digital do Portal Domínio Público. Além disso, dependendo do período histórico, as obras teatrais serão mais facilmente encontradas de forma digitalizada em tais ambientes.

A partir da seleção de obras teatrais adequadas ao nível dos participantes da SD, o professor pode selecionar fragmentos para a tradução, considerando a maior ocorrência da variação nas formas de tratamento para $2^{\mathrm{a}}$ pessoa, além da relevância do fragmento para o enredo da obra. Também, a definição do encargo de tradução didático ou, ainda, a opção por um projeto de tradução são de suma importância. Pois, a partir desta escolha, poder-se-á identificar as condições de produção do TM e o seu objetivo.

Sobre a criação dos módulos, estes deverão levar em conta as dificuldades apresentadas na análise pré-tradutória e na primeira tradução. $\mathrm{O}$ modelo didático do gênero, apresentado na seção anterior, poderá auxiliar na definição das características ensináveis do gênero textual (CRISTÓVÃO, 2010). A seguir, exemplificamos o projeto inicial de uma SD a partir da tradução do gênero textual peça teatral de comédia:

uadro 5. Projeto inicial de uma SD com a tradução de peças teatrais.

\begin{tabular}{|c|lrl|}
\hline \multicolumn{2}{|c|}{ SEQUÊNCIA DIDÁTICA COM A TRADUÇÃO DO GÊNERO PEÇA } \\
\hline Etapas & \multicolumn{1}{|c|}{ Passos } \\
TEATRAL
\end{tabular}




\begin{tabular}{|c|c|c|}
\hline \multirow[t]{2}{*}{$\begin{array}{c}1^{\circ} \\
\text { ETAPA }\end{array}$} & $\begin{array}{l}\text { Apresentação das } \\
\text { peças teatrais e } \\
\text { análise dos } \\
\text { fragmentos que } \\
\text { serão traduzidos }\end{array}$ & $\begin{array}{l}\text { Serão apresentados, de forma sucinta, o contexto e o } \\
\text { enredo de cada peça teatral selecionada para a SD. } \\
\text { Após esta apresentação, será pedido que os } \\
\text { participantes se dividam em grupos, para ler e analisar } \\
\text { o fragmento do texto teatral que receberão naquele } \\
\text { momento. }\end{array}$ \\
\hline & $\begin{array}{l}\text { Análise pré- } \\
\text { tradutória }\end{array}$ & $\begin{array}{l}\text { Será realizada a leitura e análise pré-tradutória } \\
\text { (NORD, 2012) dos fragmentos de peças teatrais. Nesta } \\
\text { análise, na parte intratextual, o professor poderá } \\
\text { destacar os usos das formas de tratamento. }\end{array}$ \\
\hline \multirow{2}{*}{$\begin{array}{c}2^{\circ} \\
\text { ETAPA }\end{array}$} & $\begin{array}{l}\text { Elaboração da } \\
\text { primeira tradução }\end{array}$ & $\begin{array}{l}\text { A partir das informações obtidas na análise pré- } \\
\text { tradutória de Nord (2012), os estudantes darão início a } \\
\text { primeira tradução. }\end{array}$ \\
\hline & $\begin{array}{l}\text { Módulos (1...n) e } \\
\text { listas de } \\
\text { constatações. }\end{array}$ & $\begin{array}{l}\text { Nesta etapa, os participantes realizarão módulos } \\
\text { acerca do gênero peça teatral e terão contato com } \\
\text { estudos sociolinguísticos referentes à variação } \\
\text { linguística nas formas de tratamento pronominais do } \\
\text { espanhol e do português. Além disso, caso seja } \\
\text { necessário, podem ser elaborados módulos específicos } \\
\text { sobre a tradução no par linguístico espanhol- } \\
\text { português. }\end{array}$ \\
\hline \multirow[t]{3}{*}{$\begin{array}{c}3^{\circ} \\
\text { ETAPA }\end{array}$} & $\begin{array}{l}\text { Elaboração } \\
\text { produção final }\end{array}$ & $\begin{array}{l}\text { Os estudantes retomarão a primeira tradução, } \\
\text { analisando a sua adequação ao encargo de tradução. } \\
\text { Logo, a partir das inadequações encontradas, os } \\
\text { participantes reescreverão a tradução, se necessário } \\
\text { corrigindo questões linguísticas e/ou estruturais do } \\
\text { texto traduzido. }\end{array}$ \\
\hline & $\begin{array}{l}\text { Revisão } \\
\text { traduções }\end{array}$ & $\begin{array}{l}\text { Após a escrita da tradução final, os textos podem ser } \\
\text { revisados, novamente, a partir do quadro de análise } \\
\text { pré-tradutória de Nord (2012). }\end{array}$ \\
\hline & $\begin{array}{l}\text { Circulação social } \\
\text { das traduções }\end{array}$ & $\begin{array}{l}\text { Os participantes divulgarão a tradução final do } \\
\text { fragmento de peça teatral traduzido para o seu } \\
\text { destinatário. }\end{array}$ \\
\hline
\end{tabular}

Esta sequência didática inicial não consiste em um modelo ou plano de aula, pois deve ser adaptada de acordo com o contexto e objetivos de aprendizagem, tempo disponível para as aulas, além das dificuldades apresentadas pelos estudantes ao preencher o quadro de análise pré-tradutória de Nord (2012) e/ou realizar a primeira tradução do TB. Ademais, tal prática está em consonância com a tendência atual do pós-método no Ensino de Línguas Estrangeiras, uma vez que, segundo Kumaravadivelu (2001), atualmente, extingue-se o método (que dita o que e como ensinar), em prol de uma prática docente diversificada e enraizada na realidade do dia-adia. Possibilitando, ainda, a integração entre as diferentes atividades, além da autonomia do 
aluno, que é o sujeito de sua aprendizagem, capaz de negociar e dialogar com o professor e os outros alunos.

\section{Considerações finais}

A partir do discorrido, vislumbramos uma possível aproximação da tradução funcionalista com os estudos sociolinguísticos e com os estudos sobre gêneros textuais. Deste modo, no contexto do Ensino de Línguas, propomos o uso da tradução funcionalista, explorando tal aproximação em uma SD. Pois, dependendo do encargo de tradução didático ou situação comunicativa proposta para a tradução, os aprendizes terão que adaptar suas traduções à língua e à cultura de um receptor meta específico, sendo impossibilitada a realização de uma tradução mecânica ou literal, principalmente, após a análise pré-tradutória do TB.

Desta maneira, consideramos viável a utilização de sequências didáticas com a tradução funcionalista do gênero peça teatral, para a abordagem de casos concretos de variação linguística na língua espanhola. Uma vez que na linguagem de suas personagens, principalmente nas comédias, encontramos diferentes registros e marcas dialetais regionais, sociais, etc. Logo, se o texto base está marcado dialetalmente por determinados fenômenos de variação linguística, poderá ser possibilitada ao aprendiz uma reflexão sobre a variação tanto na língua base quanto na língua meta, durante o processo tradutório. A reflexão sociolinguística, também, pode ser reforçada com a criação de módulos específicos para a análise dos condicionamentos linguísticos e extralinguísticos no uso destas formas linguísticas, nas duas línguas.

Com base no que foi exposto, reiteramos que a aplicação de sequências didáticas com o uso da tradução pode ser um procedimento didático relevante, no contexto atual do pósmétodo, já que uma SD é flexível ao contexto e aos objetivos de ensino-aprendizagem. Além disso, ela está pautada no desenvolvimento das capacidades de linguagem.

\section{Referências bibliográficas}

BARRIENTOS, B. R. R. Os quadrinhos da Mateina no ensino de espanhol língua estrangeira: à luz da tradução funcionalista. 2014. 252f. Dissertação (Mestrado em Estudos da Tradução) - Centro de Comunicação e Expressão. Universidade Federal de Santa Catarina, Florianópolis, 2014. 
BARROS, E. M. D. Gestos de ensinar e de aprender gêneros textuais: a sequência didática como instrumento de mediação. 2012. 368 f. Tese (Doutorado em Estudos da Linguagem) Centro de Letras e Ciências Humanas, Universidade Estadual de Londrina, Londrina, 2012.

BEATO-CANATO, A. P. M.; CRISTÓVÃO, V. L. L. Proposta de avaliação de sequências didáticas com foco na escrita. In: BARROS, E. M. D.; RIOS-REGISTRO, E. S. (org.) Experiências com sequências didáticas de gêneros textuais. Campinas, SP: Pontes Editores, 2014. p. 203-233.

BOLAÑOS-CUÉLLAR, S. Aproximación Sociolingüística a la Traducción. Forma y Función, no 13. p.157-192, 2000. Disponível em: http://goo.gl/rXX1rz. Acesso em: 20 mai. 2014.

BORTONI-RICARDO, S. M. Por que a tradutologia precisa da sociolinguística? In:

Nós cheguemu na escola, e agora? Sociolinguística e educação. São Paulo: $\overline{\text { Parábola }}$ Editorial, 2005. p. 103 - 126.

BRASIL, J. O. EI abordaje de los pronombres de tratamiento de segunda persona de singular en los libros didácticos de español del PNLD 2011: un análisis sociolingüístico. 2014. Monografia (Graduação em Letras Espanhol e suas Literaturas) - Centro de Humanidades I, Universidade Federal do Ceará, Fortaleza, 2014.

BRASIL. Ministério da Educação. Orientações Curriculares para o Ensino Médio Linguagens, Códigos e suas tecnologias. Brasília: Secretaria de Educação Média e Tecnológica, 2006. Disponível em: http://goo.gl/J7tjui. Acesso em: 21 out. 2014.

BRIGUGLIA, C. El reto de la traducción: la transferencia del puzzle lingüístico de Andrea Camilleri al castellano y al catalán. 2006. 116f. Tese (Doutorado em Comunicação Multilíngue: estudos da tradução literária e linguística) - Universidade Pompeu Fabra, Barcelona, 2006.

BUGEL, T. O espanhol na cidade de São Paulo: Quem ensina qual variante a quem? Dissertação (Mestrado em Estudos da Linguagem) - Instituto de Estudos da Linguagem, Universidade Estadual de Campinas, Campinas. 1998. Campinas, 1998. Disponível em: http://goo.gl/hJx6XZ. Acesso em: 20 out. 2014.

CALDERÓN CAMPOS, M. Formas de tratamiento. IN: ALEZA IZQUIERDO, M.; ENGUITA UTRILLA, J. M. (coord.), La lengua española en américa: Normas y usos actuales. Universidad de Valencia, Valencia: 2010. p. 225-236.

CARRICABURO, N. Las fórmulas de tratamiento en el español actual. Madrid: Arco Libros, S.A., 1997. 83 páginas. (Cuadernos de Lengua Española)

COSTA-HÜRBES, T. C.; SIMIONI, C. A. Sequência didática: uma proposta metodológica curricular de trabalho com os gêneros discursivos/textuais. In: BARROS, E. M. D.; RIOSREGISTRO, E. S. Experiências com sequências didáticas de gêneros textuais. Campinas: Pontes Editores, 2014. p.15-39. 
CRISTOVÃO, V. L. L. Sequências didáticas para o ensino de línguas. In: DIAS, R; CRISTOVÃO, V. L. L. O livro didático de língua estrangeira. Múltiplas perspectivas. Mercado de Letras: Campinas, SP, 2009. p. 305-344.

. O gênero quarta capa no ensino de inglês. In: DIONISIO, A. et. al. (Org.). Gêneros textuais e ensino. São Paulo: Parábola, 2010. p. 105 - 116.

DEMÉTRIO, A. P. C. A tradução como retextualização: uma proposta para o desenvolvimento da produção textual e para a ressignificação da tradução dentro do ensino de LE. 2014. 198f. Dissertação (Mestrado em Estudos da Tradução) - Centro de Comunicação e Expressão. Universidade Federal de Santa Catarina, Florianópolis, 2014.

DOLZ, J.; SCHNEUWLY, B. Genres et progression en expression orale et écrite: éléments de réflexions à propos d'une experience romande. Enjeux, 37/38, 1996, p.49-75.

1998.

. Pour um enseignement de l'oral: imitation aux genres formels à l'école. Paris: ESF,

DOLZ, J.; NOVERRAZ, M; SCHENEUWLY, B. Sequências didáticas para o oral e a escrita: apresentação de um procedimento. In: ROJO, R.; CORDEIRO, G.S. (Trad. e Org.) Gêneros orais e escritos na escola. Campinas: Mercado de Letras, 2004. p. 95-128.

FARACO, C. A. Norma culta brasileira: construção e ensino. In: ZILLES, A. M.; FARACO, C.A. (org.). Pedagogia da variação linguística: língua, diversidade e ensino. São Paulo: Parábola Editorial, 2015. p. 19-30.

FONTANELLA DE WEINBERG, B. Sistemas pronominales de tratamiento usados en el mundo hispánico. In: Bosque, I. /Demonte, V. (eds.). Gramática Descriptiva de la lengua española, 1. Madrid: RAE, 1999. p. 1399-1425.

GRANERO, V. V. Como usar o teatro na sala de aula. São Paulo: Contexto, 2011.

INSTITUTO CERVANTES VIRTUAL. Informes 2014. Disponível em: http://goo.gl/67L2vd. Acesso em: 01 dez. 15.

KRAVISKI, E. R. A. Estereótipos Culturais: o ensino de espanhol e o uso da variante argentina em sala de aula. 2007. 139f. Dissertação (Mestrado em Letras) - Centro de Ciências Humanas, Letras e Artes. Universidade Federal do Paraná, Curitiba, 2007.

KUMARAVADIVELU, B. Toward a postmethodpedagogy. TESOL Quartely, v. 35, n. 4, p. 537-604, 2001. http://dx.doi.org/10.2307/3588427

LAIÑO, M. J. A tradução pedagógica como estratégia à produção escrita em LE a partir do gênero publicidade. 2014. 234f. Tese (Doutorado em Estudos da Tradução) - Centro de Comunicação e Expressão. Universidade Federal de Santa Catarina: Florianópolis, 2014. 
LUGLI, V. C. P. Género: un instrumento didáctico común en diferentes niveles de aprendizaje. In: NADIN, O.L.; LUGLI, V.C.P. Espanhol como língua estrangeira: reflexões teóricas e propostas didáticas. Campinas: Mercado de Letras, 2013. p. 35 - 50.

MAMBRINI, E. Teatro e Variação: a colocação pronominal em duas versões de A viúva Pitorra, de João Simões Lopes Neto. 2004. 195p. Dissertação (Mestrado em Estudos da Linguagem) - Instituto de Letras, Universidade Federal do Rio Grande do Sul (UFRGS), Porto Alegre, 2004.

MARCHUSCHI, L. A. Gêneros textuais: definição e funcionalidade. In: DIONISIO, A. et. al. (Org.). Gêneros textuais e ensino. São Paulo: Parábola, 2010. p. 19-38.

MATTOS E SILVA, R. V. Contradições no ensino do português. São Paulo: Contexto, 1995.

MAYORAL, R. La traducción de la variación lingüística. Tese (Doutorado em Estudos da Tradução) - Universidade de Granada, Granada, 1998.

NASCIMENTO, E. P. Prestígio Linguístico no Ensino de Espanhol como Língua EstrangeiraO caso dos Pronombres Personales Sujeto. Studia Diversa, CCAE - UFPE, Vol. 1, No 1, p. 23 35, Out. 2007.

NORD, C. Text analysis in Translation: theory, methodology and didactic application of a model of translation-oriented text analysis. Tradução de Christiane Nord e Penelope Sparrow. Amsterdam; Atlanta: Rodopi, 1991.

- Traduciendo funciones. In: HURTADO ALBIR, A. (ed.): Estudios sobre la traducción. Castelló: Publicacions de la Universitat Jaume I, 1994. p. 97-112.

El error en la traducción: categorías y evaluación. In: HURTADO ALBIR, A. Estudios

sobre la traducción. Castelló: UniversitatJaume I, 1996. p. 91-107. Disponível em: < http://goo.gl/SdW35b > Acesso em: 20 fev.2015.

Texto base-texto meta. Un modelo funcional de análisispretraslativo. Tradução e adaptação de Cristiane Nord. Castelló de la Plana: Publicacions de laUniversitatJaume I, Espanha, 2012. http://dx.doi.org/10.6035/EstudisTraduccio.2012.19

PINTO, A. P. Gêneros discursivos e ensino de língua inglesa. In: DIONISIO, A. et. al. (Org.). Gêneros textuais e ensino. São Paulo: Parábola, 2010. p. 51-62.

PONTES, V. O. Abordagem das categorias verbais de tempo, aspecto e modalidade por livros didáticos de língua portuguesa e de língua espanhola: uma análise contrastiva. 2009. 84p. Monografia (Especialização em Linguística Aplicada) - Faculdade 7 de Setembro, Fortaleza, 2009.

. A tradução da variação linguística e o ensino de língua estrangeira: da teoria à prática docente. Caderno de Letras da UFF - Dossiê: Tradução, No 48, p.223-237, Nov. 2014. 
REISS, K.; VERMEER, H.J. Fundamentos para una teoría funcional de la traducción. Tradução de Sandra García Reina e Celia Martín de León. Madrid: EdicionesAkal, 1996. 206 p.

RYNGAERT, J.P. Introdução à análise do teatro. Tradução de Paulo Neves. São Paulo: Martins Fontes, 1995. 192p.

SANTOS, H. S. O papel de estereótipos e preconceitos na aprendizagem de línguas estrangeiras. In: ANALES DEL II CONGRESO BRASILEÑO DE HISPANISTAS, 2002, São Paulo, SP, Brasil. Disponível em: http://goo.gl/csrwze. Acesso em: 05 nov.2014.

SCHERRE, M. M. P, et. al. Variação dos pronomes Tu e você. In: MARTINS, M.A; ABRAÇADO, J. (org.). Mapeamento sociolinguístico do português brasileiro. São Paulo: Contexto, 2015. p.133-172.

STUTZ, L; CRISTÓVÃO, V. L. L. A construção de uma sequência didática na formação docente inicial de língua inglesa. Revista Signum: Estud. Ling., Londrina, $n^{\circ}$ 14/1, p. 569-589, 2011.

TRAVAGLIA, N. G. Tradução retextualização: a tradução numa perspectiva textual. $2^{\mathrm{a}} \mathrm{ed}$. Uberlândia: EDUFU, 2013. 308 p.

UBERSFELD, A. Para ler o teatro. Tradução de José Simões (coord.). São Paulo: Perspectiva 2005.

ZIPSER, M. E.; POLCHLOPEK, S. A. Introdução aos Estudos da Tradução. Curso de Licenciatura de Letras Espanhol na Modalidade a Distância. Florianópolis: UFSC, 2011. 